\title{
Johan Vilhelm Snellmanin sivistyskäsitys, aikuiskasvatus ja työ
}

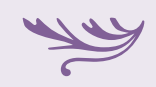

\begin{abstract}
Kansallisfilosofimme Johan Vilhelm Snellmanin (1806-1881) historiallinen ja kulttuurinen sivistyskäsite sopii uudelleen tulkittuna aikuiskasvatuspolitiikan

ja -tutkimuksen lähtökohdaksi paremmin kuin kognitiiviset näkemykset oppimisesta tai ylikansallisten järjestöjen lanseeraama kompetenssin käsite.

Sivistys vaatii inmiseltä ymmärrystä aikakautensa suurista kysymyksistä sekä toimintaa niiden ratkaisemiseksi. Työ tulkitaan sivistyksen tilaksi, jonka kautta yksilö liittyy yhteiskuntaan ja osallistuu yhteisen hyvän rakentamiseen.
\end{abstract}

Elinympäristömme ja työelämän olosuhteet muuttuvat nopeasti. Muutoksen luonnetta on vaikea hahmottaa, joten niin yksilöiden kuin instituutioidenkin on vaikea tietää, mitä tarkkaan ottaen pitäisi oppia. Kansainväliset järjestöt, IT-alan suuryritykset ja kansalliset hallinnotkin ovat 2000-luvulla talousjärjestö OECD:n johdolla pyrkineet ratkaisemaan tätä ongelmaa omaksumalla 21. vuosisadan kompetenssin tai avaintaidon käsitteen.

Suuntaa näytti OECD vuosina 1997-2002 toteuttamallaan kompetenssien määrittelyprojektilla: "[r] aportti Avaintaidot menestyksekästä elämää ja toimivaa yhteiskuntaa varten antaa perustavan panoksensa sen ymmärtämiselle, mitä on olla kilpailukykyinen yksilö ja kuinka investointi inhimilliseen pääomaan, erityisesti avaintaitoihin, voi hyödyttää sekä yksilöä että yhteiskuntaa”, sen loppuraportissa todetaan (OECD 2003, 2). OECD korosti kompetenssin käsitteellä taloutta ja kilpailua, mutta sivuutti yksilön moraaliset velvollisuudet tai ilmastonmuutoksen ja luontokadon kaltaiset ihmiskunnan suuret ongelmat (Miettinen 2019).

EU omaksui kompetenssin käsitteen määritellessään vuonna 2006 kahdeksan elinikäisen oppimisen avaintaitoa (key competencies for lifelong learning, European Union 2007). 2010-luvulla 'kompetenssi' ulotettiin kestävään kehitykseen ja maailmankansalaisuuteen (Auld \& Morris 2019; UNESCO 2017; OECD 2019). 'Kompetenssille' annettuja erilaisia merkityksiä yhdistää pyrkimys määritellä kaikille maailman ihmisille yhteiset taidot tai ominaisuudet, jotka turvaavat sopeutumisen muuttuviin oloihin.

Kompentenssin käsitteessä on kaksi olennaista ongelmaa: Ensinnäkin kasvatuksen ja koulutuksen kohteeksi mielletään siinä erillinen, yhteyksistään irrotettu yksilö, jonka osaamista ja arvoja koulutuksen ja kasvatuksen tulisi muuttaa. Toiseksi kompetenssien ja osaamisten muotoilusta osana oppilaitosten ja organisaatioiden toimintaa on kehittymässä toiveajattelun kulttuuri. 
KUN YKSILÖT IRROTETAAN

\section{YHTEISEST $\ddot{A}$ TOIMINNASTA, \\ HEIDÄT IRROTETAAN SAMALLA}

\section{TOIMINNAN JA OPPIMISEN}

\section{YHTEISKUNNALLISISTA}

MOTIIVEISTA JA

EDELLYTYKSIST $\ddot{A}$.

Kun yksilöt irrotetaan yhteisestä toiminnasta, heidät irrotetaan samalla toiminnan ja oppimisen yhteiskunnallisista motiiveista ja edellytyksistä. Esimerkiksi Unesco (2017) määrittelee kahdeksan kestävän kehityksen kompetenssia, joista ensimmäinen ja tärkein on systeeminen ajattelu, kyky analysoida monimutkaisia järjestelmiä ja suhteita. Voiko kuitenkaan olettaa, että yksilöllä olisi kyky analysoida ja ymmärtää esimerkiksi talouden ja tuotannon, ilmastonmuutoksen, luontokadon ja ruoantuotannon välisiä riippuvuuksia?

Globaalien ongelmien hahmottamiseksi ja ratkaisemiseksi tarvitaan rajojen ylittämistä, monialaista yhteistyötä ja jaettua asiantuntemusta. Esimerkkeinä ovat sellaiset institutionaaliset toimijat kuin hallitustenvälinen ilmastonmuutospaneeli IPCC (Intergovernmental Panel on Climate Change) ja hallitustenvälinen luontopaneeli IPBES sekä niiden kanssa yhteistyötä tekevät kansalliset paneelit. Niiden tehtävänä on arvioida ilmastonmuutosta ja luonnon monimuotoisuuden muutoksia koskevaa tutkimustietoa ja ehdottaa tarvittavia toimia. Paneelit kokoavat alan tutkijoista työryhmät ja verkoston tehtäväänsä varten sekä neuvottelevat hallitusten ympäristöpolitiikasta vastaavien virkamiesten kanssa. Kansainvälinen ilmastopaneeli arvioi vuoden 2008 raporttiaan varten 108277 tieteellisen julkaisun tulokset. Raportin kirjoittamisen ja sen vertaisarviointiin osallistui 3500 tutkijaa (Paglia \& Parker 2020, 308). Paneelin yleiskokouksissa tutkijat ja osanottajavaltioiden virkamiehet kirjoittavat suosituksia ilmastopolitiikkaa varten. IPCC on ilmastotieteen uudenlainen hajautettu auktoriteetti ja rajaorganisaatio tieteen ja politiikan välillä.
IPCC-raporteilla on perusteltu kansanvälisiä sopimuksia, ja kansalaisliikkeet, kuten koululaisten ilmastoliike, ovat vedonneet niihin vaatiessaan poliitikkoja ryhtymään toimiin globaalien ongelmien ratkaisemiseksi. Paikallisesti monitahoisten riippuvuuksien ja vaikkapa luontokadon tutkiminen edellyttää laajaa yhteistyötä. ${ }^{1}$ Siksi koulutuksessa on yksilön kyvyn sijaan korostettava paneutumista tiedeyhteisöjen ja asiantuntijapaneelien työhön ja tuloksiin sekä oppilaitosten yhteistyötä tutkijoiden ja ympäristöjärjestöjen kanssa. Aikuiskasvatusta tarvitaan tukemaan jaetun asiantuntemuksen ja vastuun rakentamista yhteiskunnan monimutkaisten ongelmien ratkaisemiseksi (Hakkarainen ym. 2012).

Toinen kompetenssikielen ongelma syntyy, kun kaikki tärkeänä ja tavoittelemisen arvoisena pidetty muotoillaan tavoiteltaviksi kompetensseiksi tai osaamisiksi. Ammattikorkeakoulujen osaamisiksi on määritelty muun muassa reflektio-osaaminen, verkosto-osaaminen, innovaatio-, tutkimus- ja kehitysosaaminen (Nummela ym. 2008) sekä pysähtymisen, yksilön vahvistumisen ja ympäröivän todellisuuden ymmärtämisen kompetensseja (Siiriä ym. 2018). Epäselväksi jää, mikä on näiden kompetenssien konkreettinen sisältö ja minkälaiseen tietoon, menetelmiin ja välineisiin niiden saavuttaminen voi perustua. Kasvatusfilosofi John Dewey (Dewey 1988 [1922], 22) on todennut, että "magiikan periaate toteutuu aina kun tuloksia toivotaan saavutettavan ilman välineiden älykästä hallintaa”. Abstrakteista kompetenssin määritelmistä ei voida johtaa opetuksen sisältöjä ja menettelytapoja.

Syntyvaiheessaan 1800-luvun lopulla suomalainen vapaa kasansivistystyö ja aikuiskasvatus nojautuivat vahvasti Snellmanin käsitykseen sivistyksestä ja kansallisen kulttuurin kehityksen edellytyksistä. Jokaisen sukupolven kehitys ja oppiminen perustuivat ihmiskunnan siihenastisten saavutusten kriittiseen omaksumiseen ja luovaan kehittämiseen yhteiskunnan ongelmien ratkaisemiseksi. Snellmanin käsitys tarjoaa yhä ajanmukaisen tiedon avulla uudelleen tulkittuna aikuiskasvatuksen ja koulutuksen kehittämiselle paremman lähtökohdan kuin kompetenssi- ja osaamisajattelu. 
SNELLMANIN YLEISINHIMILLINEN JA HISTORIALLINEN IHMIS- JA OPPIMISNÄKEMYS

Snellman määritteli sivistyskäsitettään muun muassa kirjoituksissaan "Akateemisesta opetuksesta" (1840) ja "Sivistys ja yleishenki" (1846). Hän luonnehti "Akateemisesta opiskelusta" -esseessään sivistysprosessia ja ihmistä sen subjektina seuraavasti (KT 2, 459):

"[J]okaisen ajan sivistys on olemassa vain omana aikanaan, niissä yksilöissä, jotka sinä aikana elävät ja vaikuttavat. Jos sivistyksestä tehdään koskaan saavuttamaton päämäärä, jokaisen ajankohdan sivistyksen ulkopuolella oleva, niin kielletään ihmisyys. [--] Edellisestä seuraa, että ihminen voidaan käsittää ajattelevana ja tahtovana subjektina, itsetietoisuutena ainoastaan yhteydessään annettuun perinteeseen ja olemassa olevaan oikeustilaan, yhteiskuntaan."

Snellmanin sivistyskäsitteestä tuli Suomen ensimmäisen tasavallan vapaan kansansivistystyön perusta, johon niin Santeri Alkio, Väinö Voionmaa kuin Zachris Castrénkin vetosivat katsomustensa eroista huolimatta. Vasta toisen maailmansodan jälkeen kansansivistysopin ensimmäinen professori Urpo Harva korvasi 'sivistyksen' englanninkielisestä maailmasta omaksutulla 'aikuiskasvatuksella' (adult education). Hän totesi $(1955,33)$, "ettei ammatillinen sivistys kuulu aikuiskasvatusopin puitteisiin siitä syystä, että aikuiskasvatusoppi käsittelee vain yleissivistykseen tähtäävää kasvatusta”. Näin käynnistyi vuosikymmenien mittainen, vapaan kansansivistystyön ja työelämän ja ammattiin suuntautuvan kasvatuksen välinen hedelmätön vastakkainasettelu.

Suomalaisessa kasvatustieteellisessä keskustelussa Snellman sivistyskäsitteineen on aina viime vuosi-

\section{KAIKKI KESKEISET}

SIVISTYSTEOREETIKOT

\section{KOROSTIVAT SIVISTYKSEN}

KUULUVAN KAIKILLE. kymmeniin asti jäänyt vähäiselle huomiolle (Uljens 2007). Esimerkiksi suomalaisten kasvatustieteilijöiden kirjoituksia kokoava teos Kasvatus ja sivistys (Siljander 2000) ei mainitse lainkaan Snellmania. Syitä on monia.

Ensinnäkin Snellman perusti ajattelunsa saksalaisen Georg Wilhelm Friedrich Hegelin (1770-1831) filosofiaan. 1900-luvulla hallinnut loogisen empirismin filosofia piti Hegelin idealistista hengen filosofiaa hämäräperäisenä spekulaationa ja epäili sen valtiokäsityksen johtaneen Euroopan 1900-luvun totalitaaristen hallintojen syntyyn. Hegel löydettiin uudelleen 1990- ja 2000-luvuilla, ja uudet tulkinnat katsovat hänen esittäneen elinvoimaisen teorian inhimillisestä tietoisuudesta ja toimijuudesta sekä yksilön vapauden ja kehityksen institutionaalisesta ja poliittista edellytyksistä (esim. Neuhourser 2000; Pippin 2008; Miettinen 2016 ja 2017). Näissä tulkinnoissa Hegelin maailmanhengen kehitys tulkitaan ihmiskunnan toiminnaksi, joka esineellistyy kulttuuriksi ja yhteiskunnallisiksi instituutioiksi, 'objektiiviseksi hengeksi', joka on puolestaan yksilöiden kehityksen lähtökohta ja edellytys.

Snellmanin valtio- ja kansallisuuskäsitettä on puolestaan tulkittu kansainväistä yhteistyötä ja -vastuuta vieroksuvan, kansallista etua ajavan ulkopoliittisen realismin perusteluksi (Sihvola 2006). Kuten historioitsija Juha Sihvola (mt.) on osoittanut, Snellman piti kansallisen kulttuurin panosta yleisinhimilliseen kehitykseen ja aikakauden suurten ongelmien ratkaisemiseen tärkeänä. Sivistys tarkoitti "kiinnostusta ihmiskunnan korkeimpiin asioihin ja kykyä niiden edistämiseen" (KT 6, 71).

Toiseksi kasvatustiede on enenevässä määrin omaksunut perustakseen sivistyksen sijaan oppimis- ja kehityspsykologian (esim. Siljander 2000), mikä näkyy Harvan analyysissa vapaan kansansivistystyön kehityksestä ja tulevaisuudesta (Harva 1943, 23 ja 77):

"Minusta näyttää myös siltä, että vapaan kansansivistystyön historia osoittaa jatkuvasti kuljetun sivistyksen käsitteestä kasvatuksen käsitteeseen [--]. Meillä on nykyisin jokseenkin vähän tietoa aikuisen sielunelämän kehittymisestä. [--] Niin kauan kuin meillä ei ole tietoa aikuisiän psykologisesta kehitystapahtumasta, kansansivistystyö hapuilee pimeässä.” 
SNELLMANIN

SIVISTYSKÄSITE KATTAA

KANSALAISYHTEISKUNTAAN

OSALLISTUMISEN.

Yritykset rakentaa aikuisen psykologialle perustuvaa erityistä aikuiskasvatustiedettä eivät ole onnistuneet. Sen sijaan 'sivistys' yksilön, kulttuurin ja yhteiskunnan instituutioiden vuorovaikutuksen ja elinikäisen oppimisen analysoinnin viitekehyksenä on edelleen perusteltu.

Snellmanin sivistyskäsite on kansainvälisestikin kiinnostava ja elinvoimainen lähestymistapa aikuiskasvatukseen. Kyse ei ole nostalgiasta, vaan Snellmanin omia sanoja käyttäen sen ymmärtämisestä, mikä perinteessä on järjellistä eli arvokasta ja kehittämisen arvoista. Samalla on tunnistettava ja ylitettävä ne Snellmanin sivistyskäsitteen rajoitukset, jotka koskevat muun muassa miesten ja naisten tasa-arvoa ja demokratian kehittämistä. Snellmanin koottujen teosten kriittisen editioiden toimitustyö vuosina 1992-2005 ja sitä koskeva tutkimus syvensivät näkemystä Snellmanin ajattelun monipuolisuudesta ja omaperäisyydestä. Tämä tulee hyvin esiin Ilkka Niiniluodon ja Risto Vilkon toimittamassa Snellmanin syntymän 200-vuotisjuhlavuonna ilmestyneessä kokoomateoksessa J. V. Snellman - filosofi ja valtio-oppinut (2006) ja Mikko Lahtisen teoksessa Snellmanin Suomi (2006). Juhlavuoden jälkeenkin Snellman-tutkimus on jatkunut vireänä (esim. Rantala 2013; Ojanen 2016; Kallio 2021).

Snellmanin sivistyskäsite (Anttonen 1981; Miettinen 2017; Laes \& Rautiainen 2018) on sovelias erityisesti työssä tapahtuvassa aikuiskasvatuksessa. Ensinnäkään se ei rajoitu pedagogiikkaan ja aikuiskoulutusinstituutioiden antamaan opetukseen vaan kattaa kansalaisyhteiskuntaan osallistumisen: yhdistyksissä ja urheiluseuroissa toimimisen, teatterissa tai museoissa käymisen ja kirjaston tai YLE Areenan palvelujen käyttämisen.

Toiseksi se pitää työtä ja ammatteja yksilöiden yhteiskuntaan liittymisen keskeisinä mekanismeina ja työyhteisöjä potentiaalisina sivistysinstituutioina. Kolmanneksi käsitteeseen sisältyy poliittinen ja normatiivinen ulottuvuus: se koskee yksilön oikeuksia ja velvollisuuksia kansalaisena ja on demokratian edellytys. Kuten Aikuiskasvatuksen Tutkimusseuran (ATS) edeltäjän, Kansansivistyksellisen yhdistyksen perustaja T. J. Wuorenrinne totesi (1991 [1945], 164), "vapaa kansansivistys ja demokratia ovat rinnakkaisilmiöitä." Kaikki keskeiset sivistysteoreetikot korostivat sivistyksen kuuluvan kaikille ja asettivat näin koulutuksellisen tasa-arvon yhteiskuntapolitiikan päämääräksi. Neljänneksi Snellmanin sivistyskäsite on historiallinen: se liittyy yksilöiden, yhteiskunnan, kulttuurin ja luonnon muuttuviin suhteisiin. Siksi se on jatkuvasti määriteltävä uudelleen. "Se kunakin eri aikana muodostaa erään kohdan ihmiskunnan jalostamisen loppumattomalla uralla" (Snellman KT 9, 438).

"Akateemisesta opiskelusta" on erinomainen esitys Snellmanin tieto- ja oppimiskäsityksestä. Se nostaa yksilön ja kulttuuriperinnön suhteen sivistyksen ja oppimisen avainkysymykseksi. Kulttuuriperintö viittaa ihmiskunnan, toisin sanoen kansakuntien, tiede-, taide- ja ammattiyhteisöjen siihenastisiin saavutuksiin. Snellman (KT 2, 456) pitää tietoa sekä yksilöstä riippumattomana perinteenä että ajattelevan subjektin tapana ottaa tietoisuuteensa tämä sisältö. Perinteen tulkitsevassa omaksumisessa tieto muuttuu Snellmanin sanoin "omaksi vapaaksi päätökseksi, vakaumukseksi ja oivallukseksi" (mt. 454).

Snellmanille sivistynyt ihminen on kulttuurinen innovaattori, vastuun kantaja sekä arvojen ja normien kehittäjä. Yksilön moraalista ja älyllistä autonomiaa ja vakaumusta painottava näkemys on kokonaisvaltaisempi ja käyttökelpoisempi käsitys yksilön kehityksestä - ja myös tietämisestä ja oppimisesta - kuin vallalla olevat kognitiivisen psykologian näkemykset informaation prosessoinnista tai yksilöstä maailmaa tulkitsevien selitysten rakentajana (Miettinen 2000). Näkemys on myös käyttökelpoisempi kuin koulutuspoliittisessa keskustelussa 2000-luvulla tärkeiksi nousseet 21 . vuosisadan kompetenssit ja geneeriset eli yleispätevät, erityisestä sisällöstä riippumattomat taidot, jotka erottavat oppimisen kulttuuriperinnöstä, oppiaineksen sisällöstä ja aikakauden aatevirtauksien vertailusta. 


\section{SNELLMAN PITI T $\ddot{A} R K E \ddot{A} N \ddot{A}$}

\section{KEHITT $\dddot{A} \ddot{A}$ ELINKEINOTOIMINTAA}

\section{JA TALOUDELLISTA}

TOIMELIAISUUTTA.

Snellman kehitteli sivistyskäsitettään osana Suomen 1800-luvun kansallista heräämistä ja puhui paljon kansallishengestä. Hän liitti siihen kuitenkin erottamattomasti kosmopoliittisen ulottuvuuden (KT 5, 40) toteamalla, että kansallishenki on "kansakunnalle ominainen yleisinhimillisen sivistyksen muoto." Valtio-oppi-teoksen alussa hän toteaa (mt. 38):

"Yksikään kansakunta ei voi muodostua pelkästään itseensä pitäytyen, vaan se liittyy kokonaisuudeksi vasta olemalla vuorovaikutuksessa muiden kansakuntien kanssa ja sen sivistys saa tietyn muodon suhteessa niihin [--] Riittäköön sen oivaltaminen, että erityinen kieli sisältää jo erityisen kansallisen sivistyksen ja edellyttää tätä ja että tämän sivistyksen on aina oltava yhteydessä ihmiskunnan sivistykseen." 2

Kansakuntien välisen vuorovaikutuksen ja siihen sisältyvien velvoitteiden pohdinta globalisoituvassa maailmassa kuuluu sivistyskäsitteen päivittämiseen. Ajatus sivistyksen universaalisuudesta sisältää velvoitteen tarttua ihmiskunnan suuriin kysymyksiin. "Sivistys ja yleishenki" -kirjoituksessaan (KT 9, 441) Snellman määrittelee sivistyneen ihmisen ensimmäiseksi vaatimukseksi, että hän "perheenjäsenenä, ammatissaan, kunnassaan, kansakunnassaan, ihmiskunnan suurissa kysymyksissä ymmärtää aikansa vaatimukset" ja että hänellä on "tietoa ja tahtoa edistää näitä yleisiä etuja."

Nykyhetken vaatimuksiin sisältyvät esimerkiksi toiminta ilmastonmuutoksen ja luontokadon pysäyttämiseksi. Globaalien ongelmien ratkaiseminen vaatii edelläkävijyyttä kansallisessa ilmasto- ja ympäristöpolitiikassa ja sinnikästä työtä sitovien kansainvälisen sopimuksien aikaansaamiseksi. Yhtä lailla se merkitsee velvoitetta globaalien ongelmien erityisten ilmenemis- muotojen ratkaisemiseen alueellisesti ja paikallisesti sekä yhteisöjen ja yksilöiden toiminnassa ja arkielämässä.

\section{TYÖN MUUTOS JA AMMATILLINEN SIVISTYS SNELLMANILLA}

Vapaata kansansivistystä ja "hyötyä" palvelevaa ammatillista koulutusta pidettiin aikuiskasvatustieteellisessä keskustelussa pitkään toistensa vastakohtina. Snellman sen sijaan puhui aineellisesta ja henkisestä sivistyksestä ja piti tärkeänä kehittää elinkeinotoimintaa ja taloudellista toimeliaisuutta. Kuten Snellmantutkija Mikko Lahtinen toteaa $(2014,70)$, "Snellmanille sivistys ei tule esille akateemis-korkeakulttuurisena humanismina, vaan päinvastoin, kansakunnan sivistyksen kysymykset viittaavat suoraan kysymyksiin elinkeinojen, aineellisten olojen ja yhteiskunnallisten suhteiden järjestämisestä." Snellman tarkasteli monipuolisesti työn, talouden, hyvinvoinnin ja sivistyksen välisiä riippuvuuksia. "Lähes kaikissa Snellmanin taloudellisissa kirjoituksissa esiintyvä teema koskee talouden ja sivistyksen välistä suhdetta. Teema etäännyttää hänet Hegelistä ja siten myös klassisesta poliittisesta taloustieteestä" (Patoluoto 1986, 279).

Snellmanin mielestä sivistys kuului yhteiskunnan kaikille jäsenille, ja sivistys ja hyvinvointi edellyttivät toisiaan (KT 8, 342). Vapaa elinkeinotoiminta kuitenkin aiheutti väistämättä taloudellista eriarvoisuutta, jota oli tasoitettava koulutuksella. "Mitä suuremmaksi elinkeinovapauden aiheuttaman varallisuuden ja ulkoisen hyvinvoinnin ero kasvaa, sitä välttämättömämmäksi käy tasoittaa eroa koulutuksella. Sitä tietä voidaan varakkaan omaisuutta myös jakaa oikeudenmukaisemmin kovempiosaisille" (KTS 5, 157). Sekä Snellman että Hegel näkivät yhteiskunnan integraatiota uhkaavana ongelmana sen, että elinkeinovapauteen perustuvan talous vääjämmättä jakoi ihmiset rikkaisiin ja köyhiin. Heillä ei ollut esittää ratkaisua tähän ongelmaan. Koulutus voi sitä lievittää, mutta ei poistaa.

Snellmanille ammatillisen koulutuksen sivistyksellinen ulottuvuus ilmeni siinä, miten ammatti liittyi yhteiskunnan kokonaisuuteen ja aikakauden suuriin kysymyksiin (KT 9, 440). Maanviljelijän sivistystä oli uusien viljelymenetelmien kehittäminen, tehtailijan 
sivistystä taas uusien valmistusmenetelmien kehittäminen. ”Talonpoika voi omassa piirissään pyrkiä käsittämään, mitä aika häneltä vaatii [--]. Tämä sivistyksen elementti voi olla siis olemassa missä hyvänsä yhteiskuntaluokassa ja missä hyvänsä se voi puuttua” (mt. 439). Tämän päivän sivistystä olisi kehittää sellaisia viljelymenetelmiä, jotka estävät ravinteiden huuhtoutumisen vesistöihin ja Itämereen, luoda saasteettomia energian tuotantomuotoja tai muovia korvaavia materiaaleja.

Snellmanilais-hegeliläisessä sivistyskäsityksessä työhön kuuluu emansipatorisia ja sivistäviä mahdollisuuksia. Työnsä, ammattinsa ja järjestöjensä kautta ihminen kiinnittyy yhteiskuntaan, oppii uutta, omaksuu arvoja, tulee tunnustetuksi ja antaa panoksensa yhteiskunnan ja kulttuurin kehitykseen (Miettinen 2017). Suomessa työn merkitys yksilön itsetunnolle ja hyvinvoinnille on laajasti tunnustettu. Helsingin Sanomat kommentoi pääkirjoituksessaan hallituksen suunnitelmaa 56000 osatyökykyisen työllistämistä edistävän valtionyhtiön perustamisesta ja päätti kommenttinsa (11.2.2021) näin: "[--] työpaikka tarjoaa ihmiselle itsetuntoa, merkityksen tunnetta ja keinon kiinnittyä yhteiskuntaan. Se on jokaisen oikeus."

Työn sivistykselliset merkitykset ovat työn organisoinnin ja kehittämisen tärkeä perusta. Samalla ne tarjoavat kriteereitä työyhteisöjen ja palkkatyön ulkopuolella tehtävän työn kehittämiseksi osaamisja arvoyhteisöiksi. Mutta palkkatyön kehitys on ristiriitaista. Työmarkkinat synnyttävät hierarkioita, palkkaeroja, rutiini- ja pätkätöitä eivätkä tunnustusta esimerkiksi hoivatyön arvoa. Työn sivistyksellinen potentiaali törmää usein yleisen edun ja voiton tavoittelun väliseen ristiriitaan. Esimerkiksi vanhustenhuollossa ristiriita ilmenee työntekijöiden eettisinä kriiseinä, kun työtä ei työn kustannustehokkuuden vaatimusten vuoksi tehdä mielekkäästi ja ihmisiä kunnioittavalla tavalla.

Yhteiskunnallisten ongelmien ratkaisemiseksi Suomessa on kehitetty viime vuosikymmeninä uudenlaisia monitoimijaisen yhteistyön malleja, joissa aikuiskasvatus ja -koulutus ovat tärkeässä asemassa. Asunnottomuuden poistamiseksi ja sitä koskevien ongelmien vähentämiseksi on kehitetty "asunto ensin-periaatteen" -pohjalta monitahoisen yhteistyön rakenteita. Koulutuksen ja työelämän ulkopuolelle jääneiden nuorten tukemiseksi luotiin puolestaan matalan kynnyksen palvelupiste, Ohjaamo, jossa nuorta tukevat osallistuvat nuoriso-, sosiaali- ja terveydenhuollon ja oppilaitosten ammattilaiset. Työttömyysongelman ratkaisemiseksi kehitellään mallia, jossa Kelan virkailijat siirtyvät kunnallisiin palvelupisteisiin tekemään yhteistyötä sosiaalitoimen, oppilaitosten ja alueen yrittäjien kanssa. Työelämän ja yhteiskunnan haasteiden monimutkaistuessa, ammatillisen koulutuksen uudistus edellyttää oppilaitoksilta ja työelämältä aiempaa tiiviimpää yhteistyötä.

Uudet rakenteet vaativat tekijöiden yhteistä muutostoimijuutta. Sen teoriaa ja metodologiaa on kehitetty kulttuurihistoriallisen toiminnan teorian perustuvan interventiotutkimuksen piirisissä (Haapasaari ym. 2014; Kerosuo 2014; Saari ym. 2021). Olennaista on, miten toimintaan osallistujat irrottautuvat vakiintuneesta toimintatavastaan analysoimalla siinä esiintyvien ristiriitojen syntyhistoriaa sekä etsivät ja kokeilevat uusia ratkaisuja näiden ristiriitojen ylittämiseksi (Virkkunen 2006; Sannino 2020).

\section{POHDINTA}

Snellmanin sivistyskäsitteen ensimmäinen vaatimus on "ymmärtää aikansa vaatimukset ihmiskunnan suurissa kysymyksissä" sekä tieto ja tahto näiden ongelmien ratkaisemiseen. Toiseksi tämä tapahtuu yhdessä ja yksilöllisesti omaksumalla kriittisesti ja kehittämällä edelleen ihmiskunnan kulttuuriperintöä, toisin sanoen eri tieteen ja ammattialojen luomia älyllisiä ja käytännöllisiä välineitä sekä moraalisia periaatteita. Kolmanneksi kansallinen ja yleisinhimillinen kietoutuvat toisiinsa erottamattomasti. Suomalaisten on opittava muiden saavutuksista, ja samalla heidän saavutuksensa ovat panos yleisinhimilliseen kehitykseen. Neljänneksi työ on keskeinen sivistyksen tila, joten ammatillisessa yleissivistyksessä on tärkeä ymmärtää oma tehtävä osana yhteiskuntakokonaisuutta ja ajan vaatimuksia.

Perustaltaan Snellmanin sivistyskäsitys on kestävä. Se velvoittaa aikuiskasvattajat ja aikuiskasvatuksen instituutiot pohtimaan, mitkä ovat ajan vaatimukset ja minkälaisen tiedon, välineiden ja periaatteiden 
A IKUISKASVATUSTUTKIMUKSEN

TULEE TUTKIA, TEHDÄ

N ̈̈KYV ̈̈KSI JA KEHITT $\ddot{A}$

YLIKANSALLISELLE

KOMPETENSSIAJATTELULLE

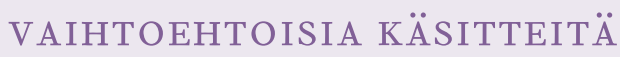

JA TOIMINTATAPOJA

avulla niihin parhaiten vastataan. Ehdotuksemme aikuiskasvatuksen kehittämiseksi on yhteiskunnan keskeisten ja eri väestöryhmien ongelmien ja kehitysmahdollisuuksien analyysi yhdessä alan toimijoiden kanssa. Ehdotukseen sisältyy sen pohtiminen, miten aikuiskasvattajat voivat antaa panoksensa ongelmien ratkaisemiseen ja yhteiskunnan eri toimintojen kehittämiseen.

1900-luvulla Snellmanin edustaman historiallisen sivistyskäsitteen ulottuvuuksia ovat kehittäneet edelleen muun muassa kulttuurihistoriallinen toiminnan teoria ja Deweyn pragmatismi, joissa oppimisen lähtökohtana on yhteiskunnan ja sen toimintojen ristiriitojen ja ongelmien ratkaiseminen (Engeström 2015 [1987]; Miettinen 1998). Kulttuurihistoriallisen psykologian perustaja Lev Vygotski (1978) osoitti kulttuuristen välineiden ratkaisevan merkityksen yksilöiden ja yhteisöjen oman toiminnan ohjaamisessa. Dewey (1988[1927]) hahmotteli teoriaa demokratiasta, joka perustui yhteiskunnallisten ongelmien yhteistoiminalliselle ratkaisemiselle. Oman aikamme ongelmien ratkaisemiseksi onkin tärkeää monitieteinen, rajoja ylittävä asiantuntemus ja yhteinen muutostoimijuus.

Snellmanin historiallista ja kulttuurista sivistyskäsitystä voi luonnehtia vertaamalla sitä kahteen 2000-luvun aikuiskasvatustutkimuksessa vahvasti esillä olleeseen lähestymistapaan: filosofi Michel Foucaultin innoittamaan hallinnan analyysiin ja ehdotuksiin ekologisiksi ja ekososiaalisiksi sivistysnäkemyksiksi. Foucaultin viitekehyksessä elinikäisen oppimisen politiikkaa ja koulutusinstituutioita analysoidaan hallinnan teknologioina, jotka ohjaavat hallinnan kohteiden pyrkimyksiä haluttuun, tietyn poliittisen "rationaliteetin" mukaiseen suuntaan (Laalo \& Jauhiainen 2019; Kinnari 2020).

Elinikäistä oppimista tutkineen Heikki Kinnarin mukaan ylikansallisten organisaatioiden, kuten OECD:n ja Euroopan unionin, elinikäisen oppimisen politiikassa on asteittain rakentunut yrittäjämäisen kansalaisuuden ihanne. Inhimillisen pääoman teoria ulottuu yksilöiden motivaatioon, asenteisiin ja persoonallisuuteen. OECD:n määrittelemien kompetenssien ja unionin avaintaitojen on määrä muokata kasvatettavia uusliberaaleiksi subjekteiksi, yrityskansalaisiksi, itsestään ja osaamisestaan kokonaisvaltaisesti huolehtiviksi ihmisiksi, kykypääomakoneiksi (Kinnari 2020). Niin aiheellinen kuin huoli onkin, analyysi ei tavoita sivistyskäsitteen emansipatorista ja uudistavaa ulottuvuutta.

Kuten pragmatistifilosofi Hilary Putnam (2001, 34) toteaa analysoidessaan vankilan ja klinikan kaltaisten instituutioiden vallan ja alistamaisen mekanismeja, Foucault ei ota lainkaan vastuuta siitä, mikä olisi vaihtoehtoinen tapa kohdella ihmisiä. Aikuiskasvatustutkimuksen tulisi vallan kritiikin lisäksi tutkia, tehdä näkyväksi ja osaltaan kehittää ylikansalliselle kompetenssiajattelulle vaihtoehtoisia käsitteitä ja toimintatapoja. Niiden yhteinen kehittely ja toimeenpano on vallan luomista tasa-arvon toteuttamiseksi.

Elinikäisen oppimisen sisällöstä ja sitä koskevista arvoista on käyty ja yhä käydään poliittista kamppailua. Hyvinvointivaltion koulujärjestelmän keskeisellä arvolla, koulutuksellisella tasa-arvolla, on yhä sekä kansalaisten että kasvatusalan ammattilaisten enemmistön vankka tuki. Pääministeri Sanna Marinin (sd) hallituksen elinikäisen oppimisen politiikkaa voidaan perustellusti tulkita yritykseksi turvata koulutuksellista tasa-arvoa rakenteellisin keinoin. Ylikansallisen politiikan vastavoimina esimerkiksi lääkärien, fysioterapeuttien, toimittajien ja opettajien ilman rajoja -järjestöt puolustavat maailmanlaajuisesti kaikkien ihmisten yhtäläisiä oikeuksia. Terveydenhuollon ammattilaiset ovat organisoineet vapaaehtoistyönä paperittomien maahanmuuttajien sairaanhoidon. Lukuisat järjestöt ja säätiöt 
työskentelevät turvatakseen marginaaliin jääneiden ryhmien ja vähemmistöjen oikeudet ja elinolot. Näiden yhteisöjen toiminnan tutkiminen ja tukeminen olisi luonteva tehtävä aikuiskasvatustutkimukselle.

Ekologiset ja ekososiaalista sivistystä korostavat lähestymistavat ovat nostaneet aiheellisesti ekologisen kestävyyden keskeiseksi uudeksi kasvatukselliseksi ja sivistykselliseksi arvoksi (Salonen \& Bardy 2015; Värri 2011). Ekososiaalisen lähestymistavan edustajat määrittelevät muutoksen keinoksi kompetenssien ohella yksilön arvo- ja merkitysperspektiivin muuttavan, transformatiivisen oppimisen (Siirilä ym. 2018; Mezirov 1981). Nämä lähestymistavat turvautuvat lisäksi muun muassa Maslowin tarveteorian ja psykoanalyysin kaltaisiin yksilöpsykologisiin ja naturalistisiin teorioihin, jotka sivuuttavat kulttuurin ja yhteiskunnallisten instituutioiden ihmisyyttä ja moraalia rakentavan vaikutuksen (Miettinen 1999).

Yksilöiden tietoisuuden muuttaminen, jos se ylipäätään on mahdollista käytännöstä irrotettuna, ei kuitenkaan riitä turvaamaan globaaleja muutoksia. Snellmanin sivistyskäsitteessä uusien arvojen on toteuduttava ihmisten yhteisessä toiminnassa ja niitä säätelevissä yhteiskunnallisissa instituutioissa, laeissa, verotuksessa, teknologisissa ratkaisuissa, jäteinfrastruktuureissa ja kansainvälisissä sopimuksissa. Näin ymmärrettynä sivistys on yksilön, kulttuurin sekä yhteiskunnan ja sen instituutioiden vastavuoroista yhteiskehitystä. Siksi tarvitaan aktivismia poliittisten päätösten ja sopimusten aikaansaamiseksi ja laajaa yhteistoimintaa työelämän ja arkisten käytäntöjen muuttamiseksi.
Muutosvaatimukset nostavat esiin aikakautemme olennaiset kysymykset, kuten ovatko talouskasvu ja vapaa markkinatalous sovitettavissa yhteen ilmastonmuutoksen ja luontokadon torjumisen kanssa. Helsingin yliopiston filosofian professori Thomas Wallgren (2020,23) esittää seuraavaa: "Näyttää siltä, että kuvitelma kestävästä kehityksestä ratkaisuna aikamme ilmasto- ja ympäristökriisiin ei voi pelastaa modernia kulttuuria sen alati kasvavasta ahdingosta, vaan se johtaa päinvastoin yhä syvempään ristiriitaan yhtäältä aineellisen kasvun tavoitteluun ja toisaalta eettisen universalismin, vapauden ja demokratian ihanteiden välillä."

Kun aikuiskasvatustieteilijät ottavat kantaa kysymyksiin, joihin ei ole valmiita vastauksia, heidän on luontevaa tehdä yhteistyötä tiedeyhteisöjen, kuten paneelien ja tutkimuslaitosten, kansalaisjärjestöjen, paikallisten liikkeiden ja kampanjoiden kanssa.

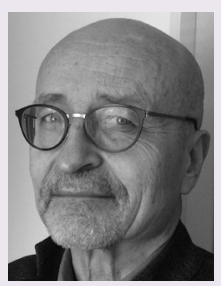

REIJO MIETTINEN

VTT, professori emeritus Helsingin yliopisto

(D) https://orcid.org/0000-00025308-4717

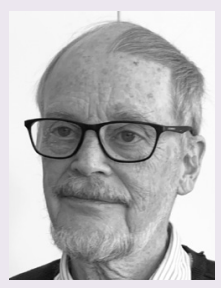

JAAKKO VIRKKUNEN

FT, professori emeritus Helsingin yliopisto

\footnotetext{
${ }^{1}$ Esimerkkinä on Suomen lintukantojen seurantahanke Suomen Lintuatlas, joka toteutetaan määräajoin tutkimuslaitosten ja paikallisten lintutieteen yhdistysten yhteistyönä. Suomi on jaettu yli $384810 \times 10 \mathrm{~km}^{2}$ ruutuun. Yhdistysten lintuharrastajat keräävät sovitun menettelyn mukaan tiedot pesivien lajien lukumäärästä ruuduilta. Tämän tuloksena linnut ovat eräs maamme parhaiten tunnetuista ja tutkituista eliöryhmistä, ja lintuja koskeva tietomme on kansainvälistä huipputasoa.

2 Tämä Snellmanin ajatus heijastaa Hegelin dialektista käsitystä yleisestä (universaalista), joka ei ole jotain erityisestä ja yksittäisestä erotettua, vaan niissä ja niiden kautta toteutuvaa.
} 
Anttonen, R. (1981). Snellmanin oppi kasvatuksesta: Lähtökohtia. Aikuiskasvatus 1(2), 45-50. https://doi. org/10.33336/aik.96181

Auld, E. \& Morris, P. (2019) Science by streetlight and the OECD's measure of global competence: A new yardstick for internationalisation? Policy Futures in Education 17(6), 677-698.

Dewey, J. (1988[1922]). Human nature and conduct. The Middle Works of John Dewey Volume 14. Edited by Jo Ann Boydston. Carbondale \& Edwardsville: Southern Illinois University Press.

Dewey, J. (1988[1926]). Public and its problems. The Later Works of John Dewey. Edited by Jo Ann Boydston. Volume 12. Carbondale: Southern Illinois University Press.

Engeström, Y. (2015[1987]). Learning by expanding. Cambridge, Mass.: Cambridge University Press.

European Union (2007). Key competences for lifelong learning. European Reference framework. Luxenbourg: Publications Office of the European Communities.

Haapasaari, A. Engeström, Y. \& Kerosuo, H. (2016). The emergence of learners' transformative agency in a Change Laboratory intervention. Journal of Education and Work 29(2), 232-262.

Hakkarainen, K., Lallimo, J., \& Toikka, S. (2012). Kollektiivinen asiantuntijuus ja jaetut tietokäytännöt. Aikuiskasvatus, 32(4), 246-256. https://doi. org/10.33336/aik.94003

Harva, U. (1943). Vapaa kansansivistystyö. Helsinki: Suomen kirja.

Harva, U. (1955). Aikuiskasvatus. Johdatus aikuiskasvatuksen teoriaan ja työmuotoihin Suomessa. Helsinki: Otava.

Kallio, L. (2021). Maailmanhenki pohjolassa. Snellman, Hegel ja Hegeliläiset. Tampere: Niin \& Näin.

Kerosuo, H. (2014). Kollektiivinen muutostoimijuus - esimerkkinä solmutyöskentely rakennusalan kehittämishankkeessa. Aikuiskasvatus 34(3), 179- 191. https://doi.org/10.33336/aik.94098

Kinnari, H. (2020). Elinikäisestä kasvajasta kykypääomakoneeksi. Elinikäinen oppiminen yrittäjämäisen talouden aikakaudella. Aikuiskasvatus 40(4), 305-319. https://doi.org/10.33336/aik.100535

Laalo, H. \& Jauhiainen, A. (2019). Yrittäjyyttä akatemiaan. Suomalaisen yliopistokoulutuksen problematisoituminen yrittäjyysdiskurssissa. Aikuiskasvatus 39(2) , 92-106. https://doi. org/10.33336/aik.82983

Laes, T. \& Rautiainen, P. (2018). Osallistuminen tieteeseen ja kulttuuriin. Elinikäinen oikeus vai velvollisuus? Aikuiskasvatus 39(2), 130-139. https://doi. org/10.33336/aik.88334
Lahtinen, M. (2006). Snellmanin Suomi. Tampere: Vastapaino.

Lahtinen, M. (2014). J.V. Snellman ja kansakunnan sivistyksen edellytykset. Teoksessa K. Kantasalmi \& M. Nest (toim.) Valistajia. sivistäjiä, poliitikkoja ja asiantuntijoita. Tampere: Tampereen yliopistopaino, 40-68.

Mezirow, J. (1981). A critical theory of adult education theory, Adult Education, 32(1), 3-24.

Miettinen, R. (1998). Miten kokemuksesta voi oppia? Kokemus ja reflektiivinen ajattelu John Deweyn toiminnan filosofiassa. Aikuiskasvatus, 18(2), 84-97. https://doi.org/10.33336/aik.92491

Miettinen, R. (1999). Abraham Maslowin ja Carl Jungin uudistavan kokemuksen käsitteet minän kehityksen malleina. Aikuiskasvatus, 19(2),128-139. https://doi. org/10.33336/aik.93217

Miettinen, R. (2000). Konstruktivistinen oppimisnäkemys ja esineellinen toiminta. Aikuiskasvatus, 20(4), 276-292. https://doi.org/10.33336/aik.93312

Miettinen, R. (2016). Sivistys kilpailuyhteiskunnassa. Mitä annettavaa Hegelillä on tänään? Kasvatus \& Aika. 10(3), 57-75.

Miettinen, R. (2017). Aikuiskasvatus, sivistys ja työn tulevaisuus. Aikuiskasvatus, 38(2), 84-95. https://doi. org/10.33336/aik.88409

Miettinen, R. (2019). 21. vuosisadan kompetenssit. OECD Kasvatuksen kielen uudistajana. Kasvatus, 50(3), 203-215.

Miettinen, R., Pehkonen, L., Lang, T. \& Pihlainen, K. (2021). Euroopan unionin elinikäisen oppimisen avaintaidot, eurooppalainen tutkintoviitekehys ja oppilaitosten opetussuunnitelmien kehittäminen. Ammattikasvatuksen aikakauskirja, 23(2), 13-31.

Neuhouser, F. (2000). Foundations of Hegel's social theory. Actualizing freedom. Cambridge, Mass.: Harvard University Press.

Niiniluoto, I. \& Vilkko, R. (toim.) (2006). J. V. Snellman filosofi ja valtio-oppinut. Helsinki: Suomen Filosofinen Yhdistys ry.

Nummela, P., Friman, M., Lampinen, O. \& Volanen, M. V. (2008). Ammattikorkeakoulut ja sivistys. Opetusministeriön julkaisuja 2008:34.

OECD (2003). Definition and selection of competencies: Theoretical and conceptual foundations (DeSeCo). Summary of the final report. https://www. oecd. org/education/skills-beyond-school/41529556.pdf (17.11.2017).

OECD (2019). OECD future of education and skills 2030. Conceptual learning framework. Transformative competencies for 2030. Paris: OECD Publishing.

Ojanen, E. (2016). Henki ja sivistys. Paikallisuuden 
näkökulma J.V. Snellmanin ajattelussa Saima-lehden 1844-1846 Kuopiota käsittelevän aineiston valossa. Kuopio: Snellman Instituutti. http://snellman. kootutteokset.fi

Paglia, E. \& Parker, C. (2020). The Intergovernmental Panel of Climate Change. Guardian of climate change. Teoksessa A. Boin, L. A. Fahy \& P. Hart (toim.). Guardians of public value. Palgrave Macmillan, 295-320.

Patoluoto, I. (1986). Sivistys kansakunnan liikuttajana. J. V. Snellmanin taloudellisten katsomusten tausta ja muotoutuminen. Teoksessa J. Manninen \& I. Patoluoto (toim.) Hyöty, sivistys, kansakunta. Suomalaista aatehistoriaa. Oulu: Pohjoinen, 271-319.

Pippin, R. B. (2008). Hegel's practical philosophy. Rational agency as ethical life. Cambridge: Cambridge University Press.

Putnam, H. (2001). Enlightenment and pragmatism. Amsterdam: Koninklijke van Gorcum.

Rantala, H. (2013). Sivistyksestä sivilisaatioon. Kulttuurikäsitys J. V. Snellmanin historiallisessa ajattelussa. Turku: Turun ylipistoin julkaisuja. Sarja C, osa 362.

Saari, E., Kurki, A.-L. \& Mattila-Holappa, P. (2021). Yksilön toimijuudesta yhteiseksi käytännöksi. Muutospajat oppilaitosten ja työpaikkojen yhteistä toimijuutta rakentamassa. Aikuiskasvatus 41(1), 18-35. https://doi.org/10.33336/aik.107386

Salonen, A. O. \& Bardy, M. (2015). Ekososiaalinen sivistys herättää luottamusta tulevaisuuteen. Aikuiskasvatus 35(1), 4-15. https://doi.org/10.33336/aik.94118

Sannino, A. (2020). Transformative agency as warping: how collectives accomplish change amidst uncertainty. Pedagogy, Culture \& Society. https://doi. org/10.1080/14681366.2020.1805493

Sihvola, J. (2006). Snellman ja ulkopolitiikka. Teoksessa I. Niiniluoto \& R. Vilkko (toim.) J.V.Snellman - filosofi ja valtio-oppinut. Helsinki: Suomen filosofinen yhdistys, 187-224.
Siirilä, J., Laininen, E. , Tikkanen, J. Salonen, A. O. \& Panzar, T. (2018). Transformatiivinen oppiminen antroposeenin ajassa. Ammattikasvatuksen aikakauskirja 20(5), 39-55.

Siljander, P. (2000). Kasvatus kadoksissa? Teoksessa P. Siljander (toim.) Kasvatus ja sivistys. Helsinki: Yliopistopaino, 15-25.

Snellman, J. V. (2000 [1840]). Akateemisesta opiskelusta. Kootut teokset, osa 2, 452-476.

Snellman. J. V. (2001[1842]). Valtio-oppi. Kootut teokset, osa 5, 32-293.

Snellman, J. V. (2002[1844]). Naiskasvatuksesta. Kootut teokset, osa 6, 70-72.

Snellman. J. V. (2002[1846]). Suomen teollisuus suomalaisen kansallisuuden ehtona. Kootut teokset, osa 8, 339-344.

Snellman, J. V. (2002[1846]). Sivistys ja yhteishenki. Kootut teokset, osa 9, 437-444.

Uljens, M. (2007). J. V. Snellman ja pedagogisen paradoksin ratkaisu. Kasvatus, 1/2007, 7-16.

UNESCO (2017). Education for Sustainable Development Gals - Learning objectives. Paris: UNESCO.

Virkkunen, J. (2006). Dilemmas in building shared transformative agency. Activités, 3(1), 43-66.

Vygotsky, L. S. (1978). Mind in Society. The development of higher mental functions. Cambridge, Mass.: Harvard University Press.

Värri, V.-M. (2011). Vastuu ihmisen mittana. Kasvatusteoreettisia ja filosofisia näköaloja ekologiselle sivistysprojektille. Tiedepolitiikka, 4/2011, 27-38.

Wallgren, T. (2020). Filosofi keppiä heiluttamassa. Niin \& Näin, 106, 21-25.

Wuorenrinne, T. I. (1991[1924]). Kansavalistuksesta kansansivistykseen. Teoksessa R. Aaltonen \& J. Tuomisto (toim). Valistus, sivistys, kasvatus. Vapaan sivistystyön XXXII vuosikirja. Jyväskylä: Gummerus, 90-107. 